\title{
Environment and Indonesian Language Learning
}

\author{
By: Silta Yulia \\ Siltayulia6153@gmail.com
}

Environmental damage is one of the major problems that does not only occur in Indonesia, but is a major problrm facing the world. All countries in the world feel the bad impact caused by environmental damage caused by greedy and irresponsible human activities. According to Mitsuki and Lai (in Ramadhan et al, 2019), all over the world, everyone faces serious environmental problems, such as global warming, acid rain, destruction of the ozone layer, environmental pollution, natural damage, and loss of biodiversity can threaten the lives of generations. to come. Environmental problems are caused by careless and intensive human activities in natural areas to improve their quality of life. A more threatening aspect is the unconscious influence of humans on their environment. Environmental degradation results in an ecological crisis that will cause a series of problems with natural resources, climate, pollution, food and the economy.

Environmental education can be considered as key because it encourages individuals to protect the environment from local potential and existing global environmental challenges (Sukma, Ramadhan and Indriyani, 2020). In line with this, Amalia, Sukma and Asma (2015) in their research entitled "Learning to Write Experimental Reports with a Scientific Approach in Elementary Schools" concluded that motivating students to learn to write in real terms is because they collect data themselves from objects or experimental phenomena to be written. In his report, students feel challenged to explore their curiosity about natural phenomena, please students because they feel proud to be able to participate in writing activities, and arouse students' interest in writing because they can publish the results of their experiments in written form. For this reason, education is needed on the importance of protecting the environment so that it is not damaged and extinct. We can make this a topic in Indonesian language learning.

Sukma and Indriyani (2019) who explained that the level of students' knowledge and awareness of the environment was still low so that teachers needed to increase knowledge about the environment and disaster mitigation so that they could design language learning with environmental education and disaster mitigation. In line with this, Sari, Ramadhan and Rasyid (2018) state that teachers are a very decisive component in implementing a strategy in making the learning process effective. 
In addition, Buldur and Omeroglu (in Ramadhan et al, 2019), also argue that environmental education is important to increase students' attitudes and awareness of the environment. Environmental education should be designed to contribute to the cognitive, emotional, linguistic and psychomotor development of students, and enable them to develop positive attitudes toward the environment. In addition, teachers must also be able to develop students' abilities to understand, criticize, and participate rationally in any discourse about environmental problems.

According to Nazarenko and Bergman (in Ramadhan et al, 2019) teachers play important roles in teaching environmental education and raise students' awareness about the environment. According to Hauchild, Poltavhenko and Stoller (in Ramadhan et al, 2019) also stated that language teachers are in a unique position to promote awareness of the environment.

If it is connected with Indonesian, the topic of environment can be included in Indonesian language learning in the form of text, this is because these topics can also be integrated into other subjects (Ramadhan et al, 2019). Rivers (in Ramadhan et al, 2019) also said that as language teachers, we are the luckiest teachers, all subjects are ours. Whatever students want to communicate, whatever they want to read is our subject matter. So, Indonesian is a very important subject to master.

The data in this paper comes from the distribution of a questionnaire via watsapp which contains ten statements with the options to strongly agree, agree, disagree and disagree. The theme of the questionnaire was the Relationship between Indonesian Language Learning and the Environment which was given to 40 respondents consisting of $62.5 \%$ women and $37.5 \%$ men and $95 \%$ students, $2.5 \%$ teachers and $2.5 \%$ students. Respondents of this study consisted of several universities and schools such as UNAND, UNP, STKIP PGRI, Taman Siswa, UNNES, Stikes Indonesia, UPI YPTK, UIN Imam Bonjol, STMIK Akakom Yogyakarta, SMKN 9 Padang, STIKes Mercubaktijaya Padang, UBH. as follows.

First, material about the environment is important in learning Indonesian. $52.5 \%$ strongly agree, $47.25 \%$ agree, $0 \%$ disagree and $0 \%$ disagree.

Second, the process of recycling used goods into useful items can be used as a procedural text. 55\% agreed, $45 \%$ strongly agreed, $0 \%$ disagreed and $0 \%$ disagreed.

Third, environmental material is closely related to everyday life. $57.5 \%$ strongly agree, $42.5 \%$ agree, $0 \%$ disagree and $0 \%$ disagree. 
Fourth, one of the external factors that affect student learning outcomes is the environment. 50\% agreed, $45 \%$ strongly agreed, $5 \%$ disagreed and $0 \%$ disagreed.

Fifth, learning Indonesian can improve students' communication skills in a social environment. $65 \%$ strongly agree, $32.5 \%$ agree, $2.5 \%$ disagree and $0 \%$ disagree.

Sixth, efforts to keep the environment clean can be done in the Indonesian language learning process. 55\% agreed, 35\% strongly agreed, $7.5 \%$ disagreed and $2.5 \%$ disagreed.

Seventh, the vocabulary that is mastered by students is obtained from the surrounding environment. $60 \%$ agreed, $30 \%$ strongly agreed, $10 \%$ disagreed and $0 \%$ disagreed.

Eighth, based on the experiences obtained from the environment through the five senses, students can make short stories. $65 \%$ agreed, $25 \%$ strongly agreed, $10 \%$ disagreed and $0 \%$ disagreed.

Ninth, the environment can develop students' imagination in learning Indonesian. $55 \%$ agree, $40 \%$ strongly agree, $5 \%$ disagree and $0 \%$ disagree.

Tenth, learning Indonesian about the environment directly or indirectly fosters students' concern for the environment. 55\% agreed, $35 \%$ strongly agreed, $7.5 \%$ disagreed and $2.5 \%$ disagreed.

From the results of research conducted through filling out a questionnaire distributed through watsapp, it can be concluded that many students, students and teachers agree and even strongly agree to include material about the environment into Indonesian language learning. Through learning Indonesian with the theme of the environment, more or less students are motivated to recognize and protect the surrounding environment so that it is not damaged and polluted. 


\section{References}

Amin, Irzal, Syahrul R, dan Ermanto. (2013). CERITA PENAMAAN DESA DI KERINCI: Kategori dan Fungsi Sosial Teks. Jurnal Bahasa, Sastra dan Pembelajarannya

Amelia, Rizky, Elvia Sukma dan Nur Asma. (2015). Pembelajaran menulis Laporan dengan Pendekatan Saintifik di Sekolah Dasar. Prosiding Seminar Nasional Jurusan PGSD UNP. Vol. 1, No. 1

Fitri, Margian Mulya, Syahrul R., Afnita. (2018). Pengaruh Model Discovery Learning Berbantuan Media Gambar Berseri Terhadap Keterampilan Menulis Teks Eksplanasi Siswa Kelas VIII SMP Negeri 25 Padang. Jurnal Pendidikan Bahasa dan Sastra Indonesia, Vol. 1 No. 7

Indriyani, Vivi, M. Zaim, Atmazaki, dan Syahrul Ramadhan (2019). Literasi Baca Tulis dan Inovasi Kurikulum Bahasa. KEMBARA: Jurnal Keilmuan Bahasa, Sastra dan Pengajarannya. Vol. 5, No, 1

Ramadhan, S., Sukma, E., \& Indriyani, V. (2019). Environmental education and disaster mitigation trough language learning. IOP Converence Series: Earth and Environmental Science, 314012054

Sari, Yuliana, Syahrul R, dan Yulianti Rasyid. (2018) Hubungan Antara Keterampilan Membaca dengan Keterampilan Menulis Teks Laporan Hasil Observasi Siswa Kelas X SMK Negeri 3 Padang. Jurnal Pendidikan Bahasa dan Sastra Indonesia. Vol. 7, No. 3

Suardi, Indah Permatasari, Syahrul R, dan Yasnur Asri (2019). Pemerolehan Bahasa Pertama Pada Anak Usia Dini. Jurnal Pendidikan Anak Usia DIni. Vol. 3, No. 1

Sukma, Elvia, S. Ramadhan dan V Indriyani. (2020). Integration of environmental education in elementary schools. Journal of Physic: Conference Series 1481 
Sukma, Elvia, R. Mahyudin, Rahmatina dan A. Surian (2019). Problem in Oral Language Teaching In Primary School. Advance in Science, Education and Humanities Research. Vol. 301

Sukma, Elvia, Ritawati mahjuddin, dan Rizky Amelia. (2017). Literacy media Development in Improving Reading and Writing Skill of Early Class Students in Elementary School Padang Utara Padang. Advances in Science, Education and Humanities Research. Vol. 118 